\title{
$\bigwedge$ Madridge
}

\section{madridge Journal of Aquaculture Research \& Development}

interconnecting

Research Article

Open Access

\section{Preliminary study to evaluate the efficacy of bambara groundnut (Vigna subterranea $(L$. Verdc.) meal as the dietary carbohydrate source in nile tilapia, Oreochromis niloticus}

\author{
Kumar Katya*, M. Z. S. Borsra, Giva Kuppusamy, Max Herriman and Sayed Azam Ali \\ Crops for The Future(CFF), Jalan Broga, 43500, Kuala Lumpur, Malaysia
}

\section{Article Info}

*Corresponding author:
Kumar Katya
Crops for the Future
(CFF), Jalan Broga, 43500
Kuala Lumpur, Malaysia
Tel: +60386892815
Email: kumar.katya@cffresearch.org

Received: April 14, 2017

Accepted: May 10, 2017

Published: May 16, 2017

Citation: Katya K, Borsra MZS, Kuppusamy G, Herriman M, Azam-Ali SN. Preliminary study to evaluate the efficacy of bambara groundnut (Vigna subterranea(L.) Verdc.) meal as the dietary carbohydrate source in nile tilapia, Oreochromis niloticus. Madridge J Aquac Res Dev. 2017; 1(1): 13-17. doi: $10.18689 /$ mjard-1000103

Copyright: @ $₫ 2017$ The Author(s). This work is licensed under a Creative Commons Attribution 4.0 International License, which permits unrestricted use, distribution, and reproduction in any medium, provided the original work is properly cited.

Published by Madridge Publishers

\begin{abstract}
The present experiment was conducted to evaluate the effects of bambara groundnut meal (BGM) as the dietary carbohydrate source and as an alternative of dietary wheat flour in nile tilapia, Oreochromis niloticus. Results from the nutrient profile analysis of various carbohydrate ingredients showed, higher crude protein and lipid content in bambara groundnut meal followed by wheat flour, dextrin and corn starch. Whereas, dextrin was found to content lower amount of moisture compared to bambara groundnut meal, wheat flour and dextrin. Four isonitrogeonus and isocaloric diets were formulated to replace wheat flour using bambara groundnut meal at $0(\mathrm{CON}), 25\left(\mathrm{BGM}_{25}\right), 50\left(\mathrm{BGM}_{50}\right)$, and $100 \%\left(\mathrm{BGM}_{100}\right)$. Nile tilapia fish individual initial weight averaging $20 \pm 0.5 \mathrm{~g}$ (mean \pm standard deviation) were fed one of the four experimental diets at $2 \sim 3 \%$ of body weight per day for eight weeks. At the end of the experiment, there were no significant differences in the average weight gain (WG) and specific growth rate (SGR) among the group of fish fed Control, $B G M_{25}$ and $B G M_{50}$ diets $(P<0.05)$. However, WG and SGR of fish fed $B G M_{100}$ diet was significantly lower than that of fish fed $B G M_{25}$ diet $(P<0.05)$. Crude protein and crude lipid content in the fish whole body proximate composition was not much affected by the BGM inclusion as a carbohydrate source. Therefore, the overall observations from the current experiment may suggest the potential of bambara groundnut meal as the carbohydrate ingredient in omnivorous fish diets. The optimum replacement level of wheat flour using bambara groundnut meal could be greater than 50 but less than $100 \%$ of diet in nile tilapia, Oreochromis niloticus.
\end{abstract}

Keywords: Bambara groundnut; Carbohydrate; Replacement; Tilapia; Oreochromis niloticus.

\section{Introduction}

Aquaculture has become the fastest growing food-producing industry around the world; however, there is still considerable potential for increased efficiency of aquaculture through the development of nutritionally balanced and cost-effective fish feeds [1] [2]. Fish feeds account for the major portion of aquaculture production costs, determine the viability and success of any aquaculture business [3]. Interestingly, numerous studies carried out to reduce the feed cost, primarily focused to replace the expensive and limited marine ingredients fish meal and fish oil, commonly used as the source of dietary protein and lipid respectively in formulated feeds. Unfortunately, the potential of dietary carbohydrate sources in the development of nutritionally and cost effective aquaculture feeds, has not been investigated thoroughly. 
Carbohydrates well known as the cheap source of energy, also having the ability to spare more expensive protein component of diets [4] [5]. In spite of limited ability of aquatic organism to digest carbohydrates due to the limited activity of the enzyme $\alpha$-amylase [6], omnivorous fish species have been reported to efficiently utilize these macro nutrients [7] [8] [9]. Interestingly, growth promoting effects of dietary carbohydrates have also been reported in carnivorous fish species such as eels [10], rainbow trout [11] [12], catfish [13] [14]. Carbohydrate rich ingredients, being the most economical and excellent source of energy are also abundantly available around the world [15] [4]. Whereas, commercial fish feed formulations for majority of aquaculture species has historically relied upon the grain and grain products such as maize, wheat, tapioca, oat to supply their carbohydrate requirements. Among a number of commonly used carbohydrate feedstuff, wheat flour has been one of the most preferred and widely used ingredient in fish feeds. However, due to the increasing demand of wheat product in the international market for the direct and indirect human consumption, price dramatically increased from 114 US dollar to 346 US dollar per metric ton between year 2001 and 2008 [16]. In order to sustain the aquaculture production, nutrition research must be directed towards minimizing the inclusion level of such imported ingredients in fish feeds formulation. Use of locally available or unconventional feed ingredients such as root and tubers which could probably improve the feed efficiency and reduce the feed cost in aquaculture $[17,18,19]$.

Bambara groundnut meal a product derived from bambara groundnut (Vigna subterranea(L.)Verdc.), is a novel legume of African origin [20], available widely. Bambara groundnut has long been recognized as the "balance human food" due to its appreciable nutrient profile, consisting carbohydrate (63\%), protein (16.25\%) and lipid (6.3\%) [21]. Further, the essential and critical amino acid profile of bambara groundnut such as lysine $6.82 \mathrm{~g} / 16 \mathrm{gN}$, methionine $1.85 \mathrm{~g} / 16 \mathrm{gN}$ and cysteine $1.24 \mathrm{~g} / 16 \mathrm{gN}$, compare favorably to that of major plant feed stuff soybean meal $(6.24 \mathrm{~g} / 16 \mathrm{gN}$ lysine, $1.14 \mathrm{~g} / 16 \mathrm{gN}$ methionine and $1.80 \mathrm{~g} / 16 \mathrm{gN}$ cysteine) [20] [22]. Worthy to note that,in the context of nutritionally balanced and cost effective feed formulation in aquaculture, interest in the use of bambara groundnut meal has been growing recently $[13,20,23,24]$. However, limited and scattered information on bambara groundnut product as the energy/ carbohydrate source, has restricted their utilization in commercial fish feed formulation.

Tilapia (Oreochromis Sp.) as the second most cultured species after carp has become an iconic aquaculture fish species around the world. The global production of tilapia reached a historical high volume of approximately 4,000, 000 MT in $2012[25,26]$. However, due to the heavy dependence upon the imported feed ingredients, the cost of tilapia feeds have also been increasing. In order to sustain the tilapia aquaculture as a profitable industry, it has become imperative to develop cost effective diets derived from unconventional or locally available sources. Therefore, in the line of dearth of knowledge on bambara groundnut, the current experiment was conducted to evaluate the efficacy of bambara groundnut meal as the dietary carbohydrate source and wheat flour replacer in nile tilapia, Oreochromis niloticus.

\section{Materials and Methods}

\section{Experimental Design and Diets}

Bambara groundnut (Gerisik) used in this experiment was provided by BamYIELD, Crops for The Future (CFF), Kuala Lumpur, Malaysia. The shell of the bambara groundnut were removed manually and were finely ground using laboratory grinder to prepare bambara groundnut meal. All other ingredients were also finely ground and sieved manually using $0.3 \mathrm{~mm}$ diameter sieve. Four isonitrogeonus ( $37.7 \%$ crude protein) and isocaloric (14.43 kj available energy/g diet)diets were formulated to replace wheat flour using bambara groundnut meal at $0(\mathrm{CON}), 25\left(\mathrm{BGM}_{25}\right), 50\left(\mathrm{BGM}_{50}\right)$, and $100 \%$ $\left(\mathrm{BGM}_{100}\right)$. Table 1 represent the formulation and proximate composition of experimental diets used in the feeding trial. Fishmeal, soybean meal, corn gluten meal served as the major protein sources in the experimental diets; fish oil was used as the lipid source, while wheat flour was the prime carbohydrate source. Wheat flour was substituted using bambara groundnut meal at graded level and accordingly adjustments were done in other ingredients in order to balance the protein and energy content in all experimental diets.

Table 1: Formulation and proximate composition of the experimental Control diet (dry matter base)

\begin{tabular}{lcccc}
\hline Ingredients & Control & $\mathrm{BGM}_{25}$ & $\mathrm{BGM}_{50}$ & BGM $_{100}$ \\
\hline Fish meal & 10.0 & 10.0 & 10.0 & 10.0 \\
Bambara groundnut meal & 0.0 & 7.4 & 14.6 & 29.3 \\
Wheat flour & 24.0 & 18.0 & 12.0 & 0.0 \\
Soybean meal & 29.0 & 28.0 & 27.2 & 25.3 \\
Corn meal & 26.0 & 26.0 & 26.0 & 26.0 \\
Fish oil & 6.0 & 5.6 & 5.2 & 4.4 \\
Vitamin Premix & 3.0 & 3.0 & 3.0 & 3.0 \\
Mineral Premix $^{\mathrm{b}}$ & 2.0 & 2.0 & 2.0 & 2.0 \\
\hline
\end{tabular}

${ }^{1}$ (as $\mathrm{mg} / \mathrm{kg}$ in diets): ascorbic acid, 300; dl-calcium pantothenate, 150; choline bitatrate, 3,000; inositol, 150; menadione, 6; niacin, 150; pyridoxine $\cdot \mathrm{HCl}$, 15; riboflavin, 30; thiamine mononitrate, 15 ; dl- $\alpha-$ tocopherol acetate, 201; retinyl acetate, 6; biotin, 1.5; folic acid, 5.4; B12, 0.06 .

${ }^{2}$ Contains (as $\mathrm{mg} / \mathrm{kg}$ in diets): $\mathrm{NaCl}, 437.4 ; \mathrm{MgSO} 4 \cdot 7 \mathrm{H} 2 \mathrm{O}, 1,379.8$; $\mathrm{NaH} 2 \mathrm{P} 4 \cdot 2 \mathrm{H} 2 \mathrm{O}, 877.8 ; \mathrm{Ca}(\mathrm{H} 2 \mathrm{PO} 4) 2 \cdot 2 \mathrm{H} 2 \mathrm{O}, 1,366.7 ; \mathrm{KH} 2 \mathrm{PO} 4,2,414 ;$ ZnSO4.7H2O, 226.4; Fe-Citrate, 299; Ca-lactate, 3,004; MnSO4, 0.016; FeSO4, 0.0378; CuSO4, 0.00033; Calcium iodate, 0.0006; MgO, 0.00135; NaSeO3, 0.00025.

Procedures for diets preparation and storage were followed as previously described by Bai and Kim (1997). After thoroughly mixing the dry ingredients and fish oil with $30 \%$ filtered tap water, experimental diets were pelleted with a laboratory pelleting machine without heating using a 2-mm diameter module (MK-NG 1500 WSL Food grinder). All the feeds were air dried for 24 hours and after processing, all diets were kept at $-4^{\circ} \mathrm{C}$ in the cold storage until use.

\section{Experimental Fish and Feeding Trial}

Fingerling size nile tilapia, Oreochromis niloticus fish were obtained from the hatchery Biodesaru, Gelang Patah Johor, 
Malaysia. Fish were transported to the experimental station (FishPLUS laboratory, FRC, Crops for The Future) and acclimated to the experimental conditions for two weeks before the feeding trial began. During the acclimation period, fish were fed commercial diet twice daily (10:00 and 18:00 h) at approximately $3 \%$ of wet body weight per day. Nile tilapia fish individual initial weight averaging $20 \pm 0.5 \mathrm{~g}$ (mean \pm standard deviation) were distributed in to twelve aquaria. Each aquaria was then randomly assigned to one of three replicates of four experimental diets. Triplicate groups of fish were fed one of the four experimental diet twice daily (10:00 and $17 ; 00 \mathrm{~h}$ ) at approximately $2 \%$ of wet body weight/d at the beginning and $3 \%$ of wet body weight/d at the end of the feeding trial for eight weeks. Total fish weight in each aquarium was determined every 2 weeks, and the amount of feeds fed to the fish were adjusted accordingly.

The feeding trial was conducted in an indoor semirecirculation system with twelve $300 \mathrm{~L}$ aquaria receiving filtered freshwater from the center tank. Supplemental aeration was provided to maintain dissolved oxygen levels near $6.5 \pm 0.5 \mathrm{ppm}$. Water temperature was $24 \pm 1^{\circ} \mathrm{C}$ (mean \pm SD); $\mathrm{pH}$ was $7.5 \pm 0.3$ (mean $\pm \mathrm{SD}$ ) and the photoperiod was 12:12 (light: dark) also maintained throughout the experimental period.

\section{Sample Collection and Analysis}

At the end of the feeding trial, all of the fish were weighed and counted for the calculation of weight gain (WG), specific growth rate (SGR), feed conversion ratio (FCR) and survival rate.

After the final weighing, three fish were randomly collected from each aquaria and frozen at $-20^{\circ} \mathrm{C}$ for analysis. The proximate composition analysis of the experimental diets, ingredients and fish whole body was performed by the standard methods of AOAC (1995). Samples were dried to a constant weight at $105^{\circ} \mathrm{C}$ to determine moisture content. Ash was determined by incineration at $550^{\circ} \mathrm{C}$, crude lipid by soxhlet extraction using a Soxtec system 1046 (Tecator $A B$, Hoganas, Sweden), and crude protein by Kjeldahl method $(\mathrm{N} \times 6.25)$ after acid digestion.

\section{Statistical Analysis}

All data were analyzed by one-way ANOVA (Statistix 3.1, Analytical Software, St. Paul, MN, USA) to test for the effects of the dietary treatments. When a significant treatment effect was observed, a Least Significant Difference (LSD) test was used to compare means. Treatment effects were considered at $P<0.05$ level of significance.

\section{Results}

\section{Nutrient Profile of Carbohydrate Ingredients}

Table 2 shows the analyzed nutrient content of various carbohydrate ingredients commonly used in commercial fish feeds. Crude protein and lipid content were found to be higher in bambara groundnut meal followed by wheat flour, dextrin and corn starch. Whereas, dextrin was found to content lower amount of moisture compared to bambara groundnut meal, wheat flour and dextrin. On the other hand, almost similar ash content was found in all these analyzed carbohydrate ingredients. Fiber content was found bellow the detection level in wheat flour and dextrin. Overall analyzed data suggested, bambara groundnut meal and wheat flour as the closely resembling carbohydrate sources.

Table 2: Analyzed nutrient composition of carbohydrate ingredients

\begin{tabular}{|c|c|c|c|c|c|}
\hline & $\begin{array}{c}\text { Crude } \\
\text { protein }\end{array}$ & $\begin{array}{c}\text { Crude } \\
\text { lipid }\end{array}$ & $\begin{array}{c}\text { Crude } \\
\text { ash }\end{array}$ & Moisture & Fiber \\
\hline Bambara groundnut meal & 15.30 & 6.3 & 0.38 & 11.1 & 0.34 \\
\hline Corn starch & 0.81 & 0.04 & 0.13 & 12.65 & 0.33 \\
\hline Wheat flour & 11.47 & 1.05 & 0.47 & 12.4 & $<0.1$ \\
\hline Dextrin & 1.05 & 0.6 & 0.16 & 8.27 & $<0.1$ \\
\hline
\end{tabular}

${ }^{a}$ Values are average from duplicate groups of samples

\section{Growth Performances}

The growth performances including weight gain (WG), specific growth rate (SGR), feed conversion ratio (FCR) and survival rate of nile tilapia fed different experimental diets for eight weeks have been summarized in table 3 . At the end of feeding trial, there were no significant differences in the average WG and SGR among the group of fish fed Control, $\mathrm{BGM}_{25}$ and $\mathrm{BGM}_{50}$ diets. However, WG and SGR of fish fed $B G M_{100}$ diets were significantly lower than that of fish fed $\mathrm{BGM}_{25}$ diet. Whereas, data for $\mathrm{FCR}$ showed no significant difference among the group of fish fed Control, $\mathrm{BGM}_{25^{\prime}} \mathrm{BGM}_{50^{\prime}}$ and $\mathrm{BGM}_{100}$ diets. Average survival rate numerically ranged between $84 \sim 100 \%$, without any statistical difference among different dietary treatments.

Table 3: Growth performance nile tilapia, Oreochromis niloticus fed different experimental diets for 8 weeks ${ }^{1}$

\begin{tabular}{cccccc}
\hline & \multicolumn{5}{c}{ Diets } \\
\cline { 2 - 6 } & Control & $\mathrm{BGM}_{25}$ & $\mathrm{BGM}_{50}$ & $\mathrm{BGM}_{100}$ & $\begin{array}{c}\text { Pooled } \\
\text { SEM }\end{array}$ \\
\hline $\mathrm{WG}(\%)^{2}$ & $145.5^{\mathrm{ab}}$ & $152.5^{\mathrm{a}}$ & $144.2^{\mathrm{ab}}$ & $131.2^{\mathrm{b}}$ & 11.27 \\
$\mathrm{SGR}(\%) /$ day $^{3}$ & $1.87^{\mathrm{ab}}$ & $1.92^{\mathrm{a}}$ & $1.86^{\mathrm{ab}}$ & $1.74^{\mathrm{b}}$ & 0.09 \\
$\mathrm{FCR}^{4}$ & $1.55^{\mathrm{a}}$ & $1.66^{\mathrm{a}}$ & $1.56^{\mathrm{ab}}$ & $1.67^{\mathrm{ab}}$ & 0.15 \\
\hline
\end{tabular}

${ }^{1}$ Means of triplicate groups of fish where values in the same row with different superscripts are significantly different $(P<0.05)$.

${ }^{2}$ Weight gain $(\%)=[($ final wt. - initial wt.) $) /$ initial wt. $] \times 100$.

${ }^{3}$ Specific growth rate $\left(\%\right.$ day $\left.^{-1}\right)=\left[\left(\log _{e}\right.\right.$ final wt. $-\log _{e}$ initial wt. $) /$ days $]$ $\times 100$.

${ }^{4} \mathrm{Feed}$ conversion ratio $=$ dry feed intake/wet weight gain

\section{Fish Whole Body Proximate Composition}

Whole-body proximate composition of nile tilapia fed different experimental diets for eight weeks has been shown in table 4. Fish whole body crude protein, crude lipid, moisture and fiber content were not much affected by the substitution of wheat flour and inclusion of bambara groundnut meal in different experimental diets.

Table 4: Whole body proximate composition nile tilapia Oreochromis niloticus fed different experimental diets for 8 weeks ${ }^{1}$

\begin{tabular}{|c|c|c|c|c|}
\hline & Control & BGM $_{25}$ & BGM $_{50}$ & BGM $_{100}$ \\
\hline Protein & 17.7 & 18.45 & 17.4 & 18.45 \\
\hline Lipid & 2.0 & 1.30 & 2.3 & 1.6 \\
\hline Ash & 1.8 & 2.0 & 2.0 & 2.0 \\
\hline Moisture & 78.4 & 78.05 & 78.0 & 77.15 \\
\hline
\end{tabular}

aValues are average from duplicate groups of samples 


\section{Discussion}

Wheat flour has been well known for its fairly high carbohydrate content (64 80\%), less fibre and excellent binding properties. However, price of wheat product has been increasing continuously due to growing demand for the direct human consumption. Further, growing ecological concern associated with the use of such imported ingredients, has exerted substantial pressure to evaluate the efficacy of $Z$ underutilized but nutritionally promising feedstuff in aquaculture feed formulation [2]. As a result, there has been a growing interest to replace/ reduce the inclusion level of wheat flour using less expensive, unconventional and locally available carbohydrate source in order to minimize the formulated feed cost [27]. Among such underutilized but nutritionally efficient feedstuff, interest in using bambara groundnut product has grown tremendously [13] [23] [24]. Our observations from the current experiment showed a superior nutrient profile (crude protein and crude lipid) of bambara groundnut meal compared to wheat flour, corn starch and dextrin (table 2). Whereas, previous studies have reported variations in the nutrient profile of bambara groundnut products due to differences in the landraces. In the current experiment, the nutrient profile of Gresik landrace appears inferior than the crude protein (21.92\%) and crude lipid (7.16\%) reported for bambara groundnut waste meal [23] [24]. Overall observations suggested, bambara groundnut meal could be a more nutritionally efficient alternative to wheat flour and corn starch, commonly used in commercial fish feed formulation.

Sources and inclusion level of dietary carbohydrates in fish feeds formulation directly affects the digestibility, palatability and thereby the growth performance of fed fish. The rising cost of imported ingredient such as wheat flour decreases into the profit margin of local fish farmers to such an extent that many local aquaculture enterprises are no longer profitable [28]. In the current experiment, the growth performance of nile tilapia increased with the wheat flour replacement and afterward declined, suggesting the efficacy of bambara groundnut meal to replace wheat flour up to $50 \%$ without any adverse effects on the fish growth. Likewise, couple of recent studies reported the potential of bambara groundnut product in catfish feed up to $40 \%$ of diet [23] [24]. However, our observation contradicts the report of $100 \%$ replacement of maize using bambara groundnut meal in nile tilapia [13]. The possible reason for such differences in the similar fish species observed between these two experiments, could be due to the fact that the aforementioned study only used the waste product of flour production (i.e. the seed testa), whereas our study used the whole seed (including the testa). Further studies could be recommended to compare and further confirm the superiority of bambara groundnut waste meal over whole seed meal in tilapia diets.

Fish whole body proximate composition was not much affected by the bambara groundnut meal inclusion as a carbohydrate source in the diet of tilapia. Although numerical differences were recorded, no clear trend could be drawn. Likewise, an irregular trend in the crude protein and lipid of whole body of catfish, Clarias gariepinus fed different levels of bambara groundnut meal has been reported by Aliu\&lkoko
(2016). Further, it also appears the dietary carbohydrate source such as wheat flour replacement might have limited effects on fish whole body composition [13].

In the current experiment, the gradual decline in the growth performance beyond $50 \%$ of wheat flour replacement could be due to the substantial increase in the antinutrients content. Since little information is available on the wheat flour replacement using bambara groundnut meal in nile tilapia, it is difficult to conclusively state the cause of the reduction in growth performance of fish fed $100 \%$ bambara groundnut meal diet. Whereas, fish meal replacement studies using various plant protein sources suggested, causes of the reduction in performance beyond the optimum level of replacement due to variations in protein content, amino acid profiles and digestibility, as well as the presence of some antinutritional factors and palatability depressants [2] [29] [30] [31]. Further studies are recommended to investigate the antinutreint profile and practical efficacy of different pretreatment (cooking/ gelatinization) in bambara groundnut meal for its commercial use in commercial fish feed formulations.

In conclusion, our observations from the current experiment are in the line of those of previous studies, suggesting the potential of bambara groundnut meal in commercial fish feeds. The optimum dietary replacement level of wheat flour using bambara groundnut meal, could be greater than 50 but less than $100 \%$ of diet without any adverse effects on the growth performance and whole body composition in nile tilapia, Oreochromis niloticus.

\section{Acknowledgments}

This study was conducted by FishPLUS program funded by Crops for The Future (CFF), Kuala Lumpur, Malaysia. Authors are thankful to BamYIELD team for providing the bambara groundnut and other required resources for this trial.

\section{Conflict of Interest}

This manuscript and research has no conflict of research.

\section{References}

1. Suarez JA, Tudela C, Davis D, Daugherty Z, Taynor M, et.al. Replacement of fish meal by a novel non-GM variety of soybean meal in cobia, Rachycentron canadum: Ingredient nutrient digestibility and growth performance. Aquaculture. 2013; 416-417: 328-333. doi: 10.1016/j. aquaculture.2013.09.049

2. Katya K, Yun YH, Park G, Lee JY, Gwangyeol Y, et.al. Evaluation of the Efficacy of Fermented By-product of Mushroom, Pleurotus streatus, as a Fish Meal Replacer in Juvenile Amur Catfish, Silurs asotus: Effects on Growth, Serological Characteristics and Immune Responses. Asian Australas. J. Anim. Sci. 2014; 27(10): 1478-1486. doi: 10.5713/ajas.2014.14038

3. Okorie EO, Young CK, Kim KW, Cheul MA, Lee KJ, et.al. A Review of the Optimum Feeding Rates in Olive Flounder (5 g through $525 \mathrm{~g}$ ) paralichthys olivaceus Fed the Commercial Feed. Fish. Aquat. Sci. 2014; 17(4): 391-401. doi: 10.5657/FAS.2014.0391

4. Yengko kS, Sahu NP, Pal AK, Mukherjee SC, Debnath D. Gelatinized Carbohydrates in the Diet of Catla catla Fingerlings: Effect of Levels and Sources on Nutrient Utilization, Body Composition and Tissue Enzyme Activities. Asian Australas. J. Anim. Sci. 2007; 20(1): 89 - 99. doi: 10.5713/ajas.2007.89 
5. Shiau SY. Utilization of carbohydrate in warm water fish with particular reference to tilapia, Oreochromis niloticus $\times$ O. aureus. Aquaculture. 1997; 151(1-4): 79-96. doi: 10.1016/S0044-8486(96)01491-3

6. Zainuddin, Haryati, Aslamyah S. Effect of Dietary Carbohydrate Levels and Feeding Frequencies on Growth and Carbohydrate Digestibility by White Shrimp litopenaeus vannamei Under Laboratory Conditions. J. Aquac. Res. Develp. 2014; 5: 274. doi: 10.4172/2155- 9546.1000274

7. Shikata TD, Kheyyali S, Shimeno. Regulation of carbohydrate metabolism in fish. XV. Effect of feeding rates on hepatopancrease enzymes and body composition in common carps. Bull. J. pn. Soc. Sci. Fish. 1993; 59: 835-839.

8. Shimeno S, Shikata T. Regulation of carbohydrate metabolism in fish. Effects of acclimatization temperature and feeding rate on carbohydrate metabolizing enzyme activity and lipid content of common carp. Bull. J. pn. Soc. Sci. Fish. 1993; 59: 661-666.

9. Wilson RP. Utilization of dietary carbohydrate by fish. Aquaculture. 1994; 124(1-4): 67-80. doi: 10.1016/0044-8486(94)90363-8

10. Degani $G$, Viola $S$. The protein sparing effect of carbohydrates in the diet of eels (Anguilla anguilla). Aquaculture. 1987; 64(4): 283-291. doi: 10.1016/0044-8486(87)90191-8

11. Kim JD, Kaushik SJ. Contribution of digestible energy from carbohydrates and estimation of protein/energy requirements for growth of rainbow trout. Aquaculture. 1992; 106(2): 161-169. doi: 10.1016/00448486(92)90200-5

12. Grisdale HB. Helland SJ. Replacement of protein by fat and carbohydrate in diets of Atlantic salmon (Salmo salar) at the end of the freshwater stage. Aquaculture. 1997; 152(1-4): 167-180. doi: 10.1016/S00448486(97)00003-3

13. Aliu BS, Ikoko E. Growth responses of Clariid catfish (Clarias gariepinus) fingerlings to dietary decorticated Bambara groundnut (voandzeia subterranea). Int. J. Fish. Aquatic. Studies. 2016; 4(6): 267-270.

14. Hung LT, Lazard J, Mariojouls C, Moreau Y. Comparison of starch utilization in fingerlings of two Asian catfishes from the Mekong river (pangasius bocourti sauvage, 1880, Pangasius hypophthalmus Sauvage, 1878). Aquaculture. Nutrition. 2002; 9(4): 215-222. doi: 10.1046/j.1365-2095.2003.00244.x

15. Kamalama BS, Medale F, Stephane P. Utilisation of dietary carbohydrates in farmed fishes: New insights on influencing factors, biological limitations and future strategies. Aquaculture. 2016; 467: 3-27. doi: 10.1016/j.aquaculture.2016.02.007

16. Impact of rising feed ingredient prices on aqua feeds and aquaculture production (FAO). FAO, Fisheries and aquaculture Technical Paper. 2009

17. Aderolu, Ademola Z, Lawal MO, Oladipupo, Muinat O. Processed Cocoyam Tuber as Carbohydrate Source in the Diet of Juvenile African Catfish (Clarias gariepinus). Eur. J. Sci. Res. 2009; 35 (3): 453-460.

18. Falayi BA, Balogun AM, Adebayo OT, Madu CT, Eyo AA. Leaching of Feed nutrients, economic losses to fish farming. J. Aquatic. Sci. 2003; 18 (2): 119-124.

19. Falayi BA, Balogun AM, Adebayo OT, Madu CT, Eyo AA. Comparison of seven Locally prepared starches Nigeria with sodium carboxyl methylcellulose for water stability in African catfish (clarias gariepinus) feeds. J. Sustain. Trop. Agr. Res. 2004; 9: 104-108.

20. Oso JA, Edward JB, Ogunleye OA, Majolagbe FA. Growth Response and Feed Utilization of clarias gariepinus Fingerlings Fed with Bambara Groundnut as Protein Source. J. Natural. Science. Res. 2013; 3(5).

21. Brough SH, Azam-Ali SN. The effect of soil moisture on proximate composition of Bambara groundnut (Vondeaza subterranean L.) Verdc. J. Sci. Food. Agr. 1992; 60(2): 197-203. doi: 10.1002/jsfa.2740600207.

22. Fetuga BL, Oluyemi JA, Adekoya AA, Oyenuga VA. A preliminary evaluation of Rubber seed, Beni seed and Bambara groundnut as essential amino acid sources for chicks. Nigerian. Agr. J. 1975; 12(1): 3951.

23. Fakunmoju FA, Babalola OA, ljimakinde B, Anjola OA, Orowole PF. Effect of Substituting Maize with Bambara (Voandzeia subterranea Thouars) Waste Meal in the Practical Diets of Tilapia Fingerlings. J. Fisheries. Aquatic. Sci. 2016; 11: 185-189. doi: 10.3923/jfas.2016.185.189

24. Enyidi1UD, Mgbenka BO, Replacement of Fish Meal with Bambara Nut Waste Meal in the Diets of Larval African Catfish Clarias gariepinus Burchell (1822). British. J. Appl. Sci. Techn. 2015; 5(6): 526-537. doi: 10.9734/BJAST/2015/12886

25. FAO. Yearbook on fishery statistics, 2014.

26. Bai SC, Kim KW. Effects of dietary animal protein sources on growth and body composition in Korean rockfish, Sebastes schlegeli. J. Aquaculture. 1997; 10: 77-85.

27. Rahman M, Choi J, Lee SM. Use of Distillers Dried Grain as Partial Replacement of Wheat Flour and Corn Gluten Meal in the Diet of Juvenile Black Seabream (acanthopagrus schlegelii). Turkish. J. Fisheries. Aquatic Sci. 2013; 13: 699-706. doi: 10.4194/1303-2712-v13_4_15

28. $\mathrm{Ng}$ WK. The potential use of palm kernel meal in aquaculture feeds. Aquaculture. Asia. Mag. 2003; 8: 38-39.

29. Lim SR, Choi SM, Wang XJ, Kim KW, Shin IS, et.al. Effects of dehulled soybean meal as a fish meal replacer in diets for fingerling and growing Korean rockfish, Sebastes schlegeli. Aquaculture. 2004; 231: 457-468. doi: 10.1016/j.aquaculture.2003.09.008

30. Fasakin EA, Serwata RD, Davies SJ. Comparative utilization of rendered animal derived products with or without composite mixture of soybean meal in hybrid tilapia (Oreochromis niloticus $\times$ Oreochromis mossambicus) diets. Aquaculture. 2005; 249(1-4): 329-338. doi: 10.1016/j.aquaculture.2005.02.059

31. Sun MH, Kim YC, Okorie OE, Devnath S, Yoo GY, et.al. Use of fermented fisheries by-products and soybean curd residues mixture as a fish meal replacer in diets of juvenile olive flounder, paralichthys olivaceus. J. World Aquac. Soc. 2007; 38(4): 543-549. doi: 10.1111/j.1749-7345.2007.00128.x 